\title{
35. Particle verbs in Germanic
}

1. Introduction

2. Morpho-syntactic properties of particle verbs in the Germanic languages

3. Approaches to the morpho-syntax of particle verbs in the Germanic languages

4. References

\section{Abstract}

This article provides an overview and comparison of particle verbs in the Germanic languages, giving examples of the construction in German, Dutch, Afrikaans, Yiddish, English, Icelandic, Norwegian, Faroese, Swedish and Danish. In particular, we will survey some of the basic morpho-syntactic properties of particle verbs, which have given rise to varying syntactic approaches to the phenomenon.

\section{Introduction}

The aim of this article is to give an overview of the phenomenon of particle verbs (PVs) in present-day Germanic including English. Particle verbs (also: phrasal verbs, separable (complex) verbs, verb-particle combinations) are combinations of verbs and prepositionlike elements (see also article 23 on particle-verb formation). Together, verb and particle form a close semantic unit. In some languages, notably languages in which the particle precedes the verb in the infinitive, such as German, Dutch, Yiddish and Afrikaans, this is reflected in the orthography. Examples of particle verbs are send OFF (German $A B$ schicken, Dutch oPsturen, Yiddish AVEKšikn; particles in small capitals throughout), look $U P$ (German NACHschlagen, Dutch OPzoeken, Icelandic fletta UPP, Norwegian slå OPP, Faroese sláa UPP), ring UP (German ANrufen, Dutch opbellen, Swedish ringa UPP), drink $U P$ (German AUStrinken, Dutch oPdrinken, Yiddish OJStrinkən, Faroese drekka UPP) and stand/get UP (German AUFstehen, Dutch opstaan, Afrikaans opstaan, Icelandic standa UPP). Particle verbs are a characteristic feature of the Germanic languages (e.g., Harbert 2007: 366; Holmberg and Rijkhoff 1998: 85), but they are also known in other languages or language families, for example Romance (see article 36 on particle verbs in Romance) and Hungarian (see article 37 on particle verbs in Hungarian). Semantically, a verbparticle combination may be anywhere on a scale from transparent to opaque. Particles may contribute directional, locative, resultative, temporal or aspectual meaning to the complex verb meaning, or the verb-particle combination may have an idiomatic meaning. Accordingly, a threefold distinction between compositional, idiomatic, and completive (or aspectual) verb-particle combinations has been suggested (e.g., Emonds 1985; Jackendoff 2002). As a unit, particle verbs may be intransitive (see (1)), take a nominal object (see (2)) or appear in syntactically more complex variants such as secondary predication constructions or double object constructions (see (3)). (See McIntyre 2007 and article 23 on particle-verb formation, section 2, on semantic and argument-structural properties of particle verbs, and references given there.) 
(1) Intransitive PVs

a. Another opportunity turned UP.

b. Der Film fängt $A N$.

German

The film catches Part

'The film is (just) starting.'

c. Ek staan nou OP.

Afrikaans

I stand now Part

'I'm getting up now.'

(Donaldson 1993: 263)

(2) PVs with a nominal object

a. John sparka UT hunden

Norwegian

John kicked Part the.dog

'John kicked out the dog.'

(Åfarli 1985: 75)

b. Hann gjørdi UPP snørið.

Faroese

He made Part fishing-line.the

'He wound up the fishing line.'

(Thráinsson 2007: 142)

(3) More complex variants

a. They made John out a liar.

(den Dikken 1995: 45)

b. Deir hafa sent strákunum peningana UPP. they have sent the boys the money Part

'They have sent the money up to the boys.'

(Collins and Thráinsson 1996: 435)

Icelandic

Unlike prefixes and prepositions, particles are prosodically strong, i.e. in a verb-particle combination, main stress falls on the particle and stress in this context may be contrastive. For illustration, consider the minimal pairs in (4) (underlining indicates main stress):

(4) a. German

umfahren (prefix verb; 'to drive around')

umfahren (particle verb; 'to knock down')

b. Dutch

omblazen (prefix verb; 'to blow around')

omblazen (particle verb; 'to blow down')

(Booij 2002: 23)

Particle verbs have been dealt with continually in the linguistic literature from various perspectives, such as their morpho-syntactic behaviour and representation, their semantics, but also their behaviour in language processing and acquisition (see, for example, Svenonius 1996b; Dehé et al. 2002; Haiden 2006 for overviews).

One major theoretical challenge arises from the fact that verb and particle are separable and have phrasal properties in the syntax but have characteristics of morphological 
units at the same time. Questions arise with regard to morpho-syntactic constituency ("Does the particle form an initial constituent with the verb or with a VP-internal DP/ PP?"; Haiden 2006: 345) and, for transitive particle verbs in particular, with regard to how syntax can account for the surface order.

\section{Morpho-syntactic properties of particle verbs in the Germanic languages}

All Germanic languages, except Present-day English, have in common that they are verb-second (V2); i.e. in declarative main clauses, the finite verb is preceded by exactly one constituent. English and the Scandinavian languages (Norwegian, Swedish, Danish, Icelandic, Faroese) are SVO throughout, while Dutch, German and Afrikaans are OV in subordinate clauses. Yiddish, along with English and the Scandinavian languages, is generally taken to be SVO, but traces of OV order can be observed in Modern Yiddish, among them the syntax of the passive, periphrastic verbs, clitic floating/climbing, and properties of particle verbs (Besten and Moed-van Walraven 1986; Jacobs, Prince and van der Auwera 1994; Santorini 1992; Jacobs 2005; Diesing 1997).

While particle verbs in general form a characteristic property of the Germanic languages, there is also much syntactic variation in this respect. This variation is partly determined by more general syntactic differences, such as the VO/OV parameter. More specifically, the particle is preverbal in OV languages in non-V2 contexts, but postverbal in VO languages. In all V2 languages, verb and particle are separated in V2 contexts. For transitive PVs in English and some of the Scandinavian languages, there is variation regarding the order of object and particle.

In the following sections, which outline some of the basic morpho-syntactic properties of particle verbs, the languages are grouped according to the VO/OV-parameter setting, except that Swedish and Danish are introduced in a separate section. Based on particleverb behaviour, Yiddish is grouped with the OV-languages. (Note incidentally that Vikner 2001, against Diesing 1997 and others, takes the syntactic behaviour of particle verbs as one piece of evidence in favour of present-day Yiddish as an OV language.)

\subsection{German, Yiddish, Dutch, Afrikaans}

In German, Yiddish, Dutch and Afrikaans, particles precede the verbal stem in the infinitive. The particle is postverbal in V2 contexts (see (5)-(8)) and in imperatives. Note that the languages differ with respect to the position of the nominal object in relation to the particle: the object precedes the particle in German, Dutch and Afrikaans but follows it in Yiddish.

a. infinitive: ABschicken 'to send off; lit. off-send'

German

b. V2:

Er schickt den Brief $A B$

* Er ABschickt den Brief.

He sends the letter Part

*Er schickt $A B$ den Brief.

'He sends off the letter.' 
(6) a. infinitive: AVEKšikn 'to send off; lit. away-send' Yiddish

b. V2:

Er šikt AVEK dem briv.

He sends Part the letter

'He sends off the letter.'

(Besten and Moed-van Walraven 1986: 119)

(7) a. infinitive: Opbellen 'to call/phone up; lit. up-call'

Dutch

b. V2:

Hij belt zijn moeder OP. / *Hij opbelt zijn moeder.

He calls his mother Part

'He calls up his mother.'

(van Marle 2002: 211)

(8) a. infinitive: AFskakel 'to switch off'

Afrikaans

b. V2:

Ek skakel die lig nou AF.

I turn the light now Part

'I'm turning the light off now.'

(Donaldson 1993: 374)

The particle is preverbal (non-separable) in contexts where its verb is not in second position, for example, because this position is filled by an auxiliary or another finite verb; see (9).

(9) a. Er wird den Brief ABschicken.

German

He will the letter Part.send

'He will send off the letter.'

b. Er vet AVEKšikn dem briv.

Yiddish

He will Part.send the letter

'He will send off the letter.'

(Besten and Moed-van Walraven 1986: 119)

c. Ik zal het licht UITdoen.

Dutch

I shall the light Part.do

'I'll turn off the light.'

d. Ek sal die lig AFskakel.

Afrikaans

I shall the light Part.turn

'I'll turn off the light.'

(Donaldson 1993: 374)

Inflectional affixes such as participle ge-, and infinitive markers $z u$ (German), tsu (Yiddish) and te (Dutch, Afrikaans) are inserted between particle and verb; see (10) and (11).

(10) Participles

a. ABschicken 'to send off': ABgeschickt

German

(any other forms ungrammatical)

e.g.: $\mathrm{Er}$ hat den Brief ABgeschickt.

he has the letter Part.sent (participle)

'He (has) sent off the letter.' 
b. AVEKšikn 'to send off': AVEKgešikt

Yiddish

c. Opbellen 'to call up': OBgebeld

Dutch

d. AFskakel 'to switch off': AFgeskakel

Afrikaans

e.g.: Het jy die lig AFgeskakel?

Have you the light Part.turned

'Did you turn off the light?'

(Donaldson 1993: 374)

(11) Infinitives

a. ABschicken 'to send off': ABzuschicken

German

(any other forms ungrammatical)

e.g.: Ich bat sie, den Brief für mich ABzuschicken.

I asked her the letter for me Part.inf.send

'I asked her to send off the letter for me.'

b. AVEKŠikn 'to send off': AVEKtsušikn

Yiddish

c. opbellen 'to call up': oP te bellen

Dutch

e.g.: Zij probeerde haar moeder oP te bellen

She tried her mother Part inf call

'She tried to call her mother.'

(van Marle 2002: 211)

d. AFskakel 'to switch off': AF te skakel

Afrikaans

e.g.: Ek heet vergeet om die lig $A F$ te skakel

I have forgotten the light Part inf turn

'I forgot to turn off the light.'

(Donaldson 1993: 374)

In OV subordinate clauses, particle and verb are adjacent, with the particle preceding the verb in German, Dutch and Afrikaans (see (12)).

(12) OV subordinate clause

a. dass er den Brief ABschickte.

German

that he the letter Part.sent

'that he sent off the letter'

b. dat Jan het meisje opbelt.

Dutch

that Jan the girl Part.phones

'that Jan rings up the girl'

(Neeleman and Weerman 1993: 434)

c. Ek weet dat hy die lig nooit AFskakel nie.

Afrikaans

I know that he the light not Part.turn NEG

'I know he never turns the light off.'

(Donaldson 1993: 374)

According to Besten and Moed-van Walraven (1986: 119), Yiddish is different from German, Dutch and Afrikaans in that the particle-verb order is impossible in subordinate clauses; see (13): 
(13) a. az er šikt AVEK dem briv that he sends Part the letter 'that he sends off the letter'

b. *az er AVEKŠikt dem briv

Moreover, Dutch is different in that it allows an auxiliary between the particle and the verb in subordinate clauses; see the comparison between German and Dutch in (14) and (15).

(14) Subordinate clause

Dutch

a. dat Jan het meisje wil opbellen that Jan the girl wants Part.phone 'that Jan wants to call the girl'

(Neeleman and Weerman 1993: 435)

b. dat Jan het meisje op wil bellen

(15) Subordinate clause

a. dass Jan das Mädchen ANrufen will/wird

German that Jan the girl Part.call wants/will 'that Jan wants to/will call the girl'

b. *dass Jan das Mädchen AN will rufen

In more complex constructions, such as double object particle constructions (here illustrated for two nominal objects in Dutch and German subordinate clauses), the particle is placed next to the verb (see (16)).

a. dat Jan Marie het zout DOOR gaf

Dutch that Jan Mary the salt Part gave 'that John passed Mary the salt'

(Neeleman 2002: 142); all other orders are ungrammatical

b. dass Jan Marie den Tausch ANbot.

German that Jan Mary the trade.off Part-offered 'that John offered Mary the swap'

Authors disagree as to whether or not particles may be fronted (see, for example, the discussion in Müller 2002: 263-292, Zeller 2001: 88-99, and references given there). A common assumption is that fronting is possible only if the combination of particle and verb is semantically transparent, and if the particle has a contrastive interpretation and receives contrastive stress. See the examples in (17) through (19), where semantically transparent examples are given in a), semantically opaque ones in b). Similar to fronting, speaker judgments vary as to whether or not particles may be modified, but modification is possible only for certain particles and in certain environments, for example when particles are fronted (for details, see Stiebels and Wunderlich 1994, Wurmbrand 1998 for German; Diesing 1997 for Yiddish, among others).

(17) Fronting

a. AUF hat Peter die Tür gemacht.

German

Part/open has Peter the door made

'Peter opened the door.' 
b. *AUF haben sie das Stück geführt. / Sie haben das Stück AUFgeführt.

Part have they the piece lead

'They performed the piece.'

(Wurmbrand 1998)

(18) Fronting

a. ARAYN iz er gekumen.

Yiddish

Part/in is he come

'In, he came (not out).'

b. ${ }^{*} O P$ iz dos ayz nit gegangen.

Part is the ice not gone

'The ice hasn't thawed.'

(Diesing 1997: 384)

(19) Fronting

a. AF maak ik mijn huiswerk niet.

Dutch

Part make I my homework not

'I will not finish my homework.'

b. *OP bel ik mijn moeder niet.

Part call I my mother not

'I will not call my mother.'

(Booij 2002: 24)

\subsection{English, Norwegian, Icelandic, Faroese}

In Present-day English, Norwegian, Icelandic and Faroese, particles follow the verbal stem in the infinitive (e.g., English look UP, Norwegian slå $O P P$, Icelandic fletta UPP, Faroese sláa UPP). Due to this order, these languages display contrasts between prepositional verbs and homophonous particle verbs (e.g., English look UP a word (in a dictionary) vs. look up the road (to see if someone's coming)). Their syntactic behaviour helps to tell particle and prepositional verbs apart. For example, a preposition always precedes its object, while a particle may either precede or follow a full NP object and must follow an unstressed pronominal object. Moreover, a preposition but not a particle can be fronted together with its object. This is illustrated using an Icelandic example from Thráinsson (2007: 139); see (20)-(21).

(20) Prepositional verb halda við 'to support; lit. hold with'

a. Tveir menn héldu við stigann/hann.

two men held with stairs.the/it

'Two men supported the stairs/it.'

b. *Tveir menn héldu hann við.

c. Við stigann héldu tveir menn. 
(21) Particle verb halda við 'to keep up, keep in shape'

a. Tveir menn héldu VIĐ húsinu/pví.

two men held with house.the/it

'Two men kept the house in shape.'

b. Tveir menn héldu pví við.

c. *Við húsinu héldu tveir menn.

In all four languages, transitive particle verbs show a surface alternation such that the nominal (full phrase) object may either precede or follow the particle. Pronominal objects are ungrammatical in the position following the particle unless focused and stressed accordingly. See (22)-(25).

(22) a. Sue looked UP the word $/ *^{*}$ it.

b. Sue looked the word/it UP.

c. I knew that the school board contemplated throwing out Spanish in order to throw OUT me.

(Bolinger 1971: 39; underlined pronoun focused)

(23) a. John sparka UT hunden /*den.

Norwegian

John kicked Part the.dog /it

'John kicked out the dog.'

b. John sparka hunden/den UT.

(Åfarli 1985: 75)

(24) a. Deir hafa sent UPP peningana/*bá.

Icelandic

They have sent Part the money/them

'They have sent the money/them up.'

b. Peir hafa sent peningana/pá UPP.

(Collins and Thráinsson 1996: 430)

(25) a. Hann gjørdi UPP snørið/*tað.

He made Part fishing.line.the/it

Faroese

'He wound up the fishing line.'

b. Hann gjørdi snørið/tað UPP.

(Thráinsson et al. 2004: 247)

As illustrated for Icelandic prepositional complements in (26) and clausal complements in (27), non-nominal constituents are not allowed between verb and particle:

(26) Prepositional complement

a. Jón hélt TIL hjá systrunum.

Icelandic

John held Part with the sisters

'John stayed with the sisters.' (e.g., had room and board there)

b. *Jón hélt hjá systrunum TIL.

(Thráinsson 2007: 97) 
(27) Clausal complement

a. Jón tók FRAM [að María héfði farið]. Icelandic John took Part that Mary had left.

'John explicitly mentioned that Mary had left.'

b. *Jón tók [að María héfði farið] FRAM.

(Thráinsson 2007: 97)

Several factors have been suggested in the literature as contributing to the choice of one word order over the other (for overviews focusing mostly on English, see Dehé 2002: 76-80 and Gries 2003: chapter 2). Among these factors are phonological factors such as word and sentence stress; morpho-syntactic factors such as pronominal vs. full-phrase status of the object (see (22)-(25) above), (in)definiteness, the heaviness, length or syntactic complexity of the nominal object (illustrated for Icelandic and English in (28) and (29), respectively), the presence of a directional adverbial, and modification of the particle (see (35) below); semantic and discourse factors such as the idiomaticity of the particle-verb unit or the entire verb phrase, and focus or given vs. new information (see (22c) above and (30) below); and other factors such as dialectal variation (e.g., some Norwegian dialects prefer the particle-object order, see Svenonius 1996a, 1996b). Based on a large set of English corpus data, Gries (2003) develops a multifactorial statistical approach in order to account for the interaction of some of these factors. He finds that in the multifactorial analysis, morpho-syntactic variables outrank semantic and discoursefunctional factors.

(28) NP-Heaviness

Icelandic

a. ?Stelpan bar [allar stóru töskurnar sem við komum með úr fríinu] INN. girl.the carried all big bags.the that we brought from vacation-the PART 'The girl carried all the big bags that we brought from the vacation in.'

b. Stelpan bar INN [allar stóru töskurnar sem við komum með úr fríinu].

(Thráinsson 2007: 143)

(29) NP-Heaviness

a. ??She sewed the sleeve with lace around the cuff on.

English

b. She sewed on the sleeve with lace around the cuff.

(Olsen 1996: 279)

(30) The news value of the direct object affects its position

Michael laboriously puts DOWN the bags, pushes wide the door, picks the bags UP again and enters, ...

(Dehé 2002: 130; example from Stephen Fry, Making History)

The alternation between the V-particle-object order and the V-object-particle order possible with non-pronominal objects in English, Norwegian, Icelandic and Faroese has been referred to as particle shift (PS; e.g., Svenonius 1994, 1996a, 1996b; Thráinsson 2007). On the basis of the similarities between PS in English and Icelandic, Johnson (1991) suggests that English has object shift (OS) similar to Icelandic, allowing for overt verb and object movement. However, as Thráinsson (2007: $141 \mathrm{f}$.) shows, there 
are important differences between PS and Icelandic OS, among them the fact that the presence of an auxiliary blocks the latter but not the former; see (31), from Thráinsson (2007: 141). According to Thráinsson (2007), this suggests that the object moves to a lower position in PS than in OS.
a. Ég hef aldrei flett UPP nöfnunum.
(no shift)
I have never looked Part names-the
'I have never looked up the names.'
b. Ég hef aldrei flett nöfnunum UPP.
(PS only)
c. *Ég hef nöfnunum aldrei flett UPP.
(OS blocked)

In a V2 context where the subject is non-initial, verb and particle must be separate and the particle immediately follows the subject or the object. This is illustrated in (32) for Icelandic (Collins and Thráinsson 1996: 432).
a. Í geer sendu peir peningana UPP.
Yesterday sent they the money Part
'Yesterday they sent the money up.'
b. Í geer sendu peir UPP peningana.
c. *Í gaer sendu UPP peir peningana.

In more complex constructions, such as double object particle constructions (here illustrated for two nominal objects in English and Icelandic), the following particle positions are possible (see (33) and (34)).

(33) a. *John sent oUT the stockholders a schedule.

English

b. John sent the stockholders out a schedule.

c. *John sent the stockholders a schedule ouT.

(Neeleman 2002: 141)

(34) a. *Í gaer hafa peir sent UPP strákunum peningana.

Icelandic Yesterday have they sent Part the boys the money

'Yesterday they sent the money up to the boys.'

b. (?)Í gaer hafa peir sent strákunum UPP peningana.

c. Í geer hafa peir sent strákunum peningana UPP.

As shown in (35) for Icelandic and Norwegian, modification of the particle is possible only in the V-object-particle order.

(35) Modification of the particle
a. Íger hafa peir sent peningana beint UPP.
Icelandic
Yesterday have they sent the.money straight Part.
'Yesterday they sent the money straight up.'
*Í gaer hafa peir sent beint UPP peningana.

(Collins and Thráinsson 1996: 430) 
b. John sparka hunden langt UT.

Norwegian

John kicked the.dog far Part

'John kicked the dog far out.'

*John sparka langt ut hunden.

(Åfarli 1985: 76)

\subsection{Danish and Swedish}

In Danish and Swedish, like in the other Scandinavian languages, particles follow the verbal stem in the infinitive (e.g., Danish vokse OP 'grow up'; Swedish ringa UPP 'call up'). An important difference between Danish and Swedish on the one hand and the four languages outlined in the previous section on the other, is that in Danish and Swedish, the position of the particle with respect to a nominal object is fixed: in Danish, the particle follows the object, in Swedish the particle is verb-adjacent and precedes the object, both if the object is pronominal and if it is a full phrase. While "all particles appear to be modifiable in Danish (so long as modification is semantically plausible)" (Toivonen 2003: 161), the Swedish particle cannot be modified in its verb-adjacent position (see (36)-(37); all examples from Toivonen 2002, 2003; see references given there).

(36) a. Han knugede sine honder SAMMEN. Danish he clasped his hands Part

'He clasped his hands.'

b. *Han knugede SAMMEN sine hoender.

a. Simon kastade UT soporna.

Swedish

Simon threw Part garbarge.the

'Simon threw out the garbage.'

b. *Simon kastade soporna UT.

c. ... och släpar UT honum. and drag Part him

'... and drag him out.'

d. *Olle sparkade [längre BORT] bollen.

Olle kicked further Part ball.the

'Olle kicked the ball further away.'

In Thráinsson's (2007: 142) terms, particle shift obligatorily applies in Danish, but it never applies in Swedish.

\section{Approaches to the morpho-syntax of particle verbs in the Germanic languages}

The morpho-syntactic behaviour of particle verbs, and specifically the fact that across languages they share properties with both heads and phrases, has given rise to a number 
of different analyses, which have been summarized, discussed and grouped by various authors (e.g., Dehé 2002; Dehé et al. 2002; Haiden 2006; Blom 2005; Elenbaas 2007; see also article 23 on particle-verb formation). Given these existing overviews, only a very rough overview will be provided here and the reader is referred to the references given throughout.

Approaches to particle verbs can roughly be grouped into complex predicate approaches on the one hand and non-complex-predicate approaches on the other.

Complex predicate analyses assume that verb and particle form a constituent, either a complex verbal head of the form $\mathrm{V}^{0}$ (e.g., Johnson 1991; Koizumi 1993; Neeleman and Weerman 1993; Stiebels and Wunderlich 1994; Olsen 1997, 2000; Ackerman and Webelhuth 1998; Dehé 2002; Blom 2005: 41-45 and see article 23 on particle-verb formation, for critical discussions), or a non-minimal/non-maximal verbal projection (e.g., Booij 1990; Lüdeling 2001; Zeller 2001, 2002). Non-complex-predicate approaches assume that the particle projects its own phrase, often forming a constituent with the phrase referred to as nominal object in the discussion above.

Complex head analyses have been based on their word-like properties, such as their status as a close semantic unit, the fact that particle verbs enter into word-formation processes such as derivation and compounding (see article 23 on particle-verb formation and references given there), their selectional requirements, and their behaviour in syntactic environments such as gapping constructions, co-ordination, quotative inversion and VP-fronting (see Blom 2005 and article 23 for recent discussions). Immediate problems with this analysis include the separability of verb and particle in the syntax, and the fact that the particle may be topicalised and modified separately. These properties suggest a phrasal approach to particles. Note at this stage that Swedish has arguably a special status, since verb and particle cannot be separated in the syntax and the particle cannot be modified in its verb-adjacent position. Accordingly, Toivonen (2003) suggests that Swedish particles are non-projecting words, which are head-adjoined to the verbal head.

Particle verbs have often been compared and found to be similar to resultative as well as causative, depictive, and adverb-verb constructions (Hoekstra 1988; Neeleman and Weerman 1993; Svenonius 1996b; Haider 1997; Lüdeling 2001, among others). Similarities in particular between particles and resultatives, along with other clausal properties, have been taken as evidence by some authors for a "small clause" analysis, which assumes a subject-predicate relationship between the particle and the post-verbal nominal constituent (e.g., Kayne 1985, 1998; Hoekstra 1988; den Dikken 1995; Collins and Thráinsson 1996; Svenonius 1996a, b; Ramchand and Svenonius 2002). The problematic aspects of the small clause analysis have received much attention in the literature (see Booij 1990: 54-58; Dehé 2002: 17-36, and Farrell 2005: 109-121 for critical discussions). Based on the differences in behaviour between semantically transparent (or, specifically, resultative) particle verbs and idiomatic ones, it has been suggested that only the former are best analysed as small clauses (Aarts 1989; Wurmbrand 2000). Along with the similarities between resultatives and particles, Neeleman and Weerman (1993) outline some differences, which, they argue, a small clause analysis cannot account for. Instead, they suggest that both resultatives and particles are adjoined to the verb, accounting for the similarities between them. However, while particle adjunction is a morphological process, adjunction of resultatives takes place in the syntax, accounting for the differences between the two constructions. 
Although often based on data from specific languages, very few approaches to particle verbs are explicitly language-specific and some analyses aim at a comparison between languages. Examples of the latter are given immediately below.

Zeller (2002) presents a comparative account of particle verbs in two VO languages (English, Norwegian) and two OV languages (Dutch, German). He concludes that the relevant differences with respect to particle-verb behaviour are a consequence of independent properties, such as VO/OV-parameter setting and the V2 property. Neeleman (2002) comes to a similar conclusion. In his comparative discussion of Dutch and English, he addresses the surprising observation that word order is freer in English particle constructions than in Dutch ones, despite the fact that Dutch, which allows scrambling, has less strict constituent ordering otherwise. He concludes that the two languages have identical grammars in all relevant respects, except for the setting of the OV/VO parameter. The different structures surfacing in Dutch and English are a result of the flexibility of both case and theta theory. Comparing English and German transitive particle-verb constructions, Dehé (2005) sets off from an observation similar to that made by Neeleman (2002). While English allows for PS, the only grammatical option in German V2 sentences such as $(5 \mathrm{~b})$ is particle stranding. Dehé (2005) concludes that the syntactic differences between German and English (specifically that German but not English is a V2 language) alone do not suffice to explain obligatory particle stranding in main clause contexts such as (5b), since particle pied-piping would not violate V2. Rather, couched in the optimality-theory framework, she suggests that the differences between the two languages with respect to particle placement can best be explained in terms of the interaction of syntactic and prosodic constraints and their respective ranking. Specifically, a syntactic constraint closely related to STAY (i.e. "avoid movement", Grimshaw 1997) is outranked by prosodic constraints in English but not in German. The question of whether or not the syntactic $\mathrm{VO} / \mathrm{OV}$ parameter and $\mathrm{V} 2$ property are enough to explain the crosslinguistic differences in syntactic behaviour will have to be seen in a larger context, also taking into account other types of complex predicates (see Haider 1997) and non-syntactic factors.

\section{Acknowledgements}

I would like to thank the following native speaker informants: Janet Grijzenhout (Dutch), Jóhannes Gísli Jónsson (Icelandic), Guðrið Poulsen (Faroese), as well as Kristina Kotcheva and Allison Wetterlin for discussion.

\section{References}

Aarts, Bas

1989 Verb-preposition constructions and small clauses in English. Journal of Linguistics 25: 277-290.

Ackerman, Farrell and Gert Webelhuth 1998 A Theory of Predicates. Stanford, CA: CSLI.

Åfarli, Tor A.

1985 Norwegian verb-particle constructions as causative constructions. Nordic Journal of Linguistics 8: 75-98. 
Besten, Hans den and Corretje Moed-van Walraven

1986 The syntax of verbs in Yiddish. In: Hubert Haider and Martin Prinzhorn (eds.), Verb Second Phenomena in Germanic Languages, 111-135. Dordrecht: Foris.

Blom, Corrien

2005 Complex predicates in Dutch. Synchrony and diachrony. Utrecht: LOT.

Bolinger, Dwight L.

1971 The Phrasal Verb in English. Cambridge, MA: Harvard University Press.

Booij, Geert

1990 The boundary between morphology and syntax: Separable complex verbs in Dutch. In: Geert Booij and Jap van Marle (eds.), Yearbook of Morphology 1990, 45-63. Dordrecht: Foris.

Booij, Geert

2002 Separable complex verbs in Dutch: A case of periphrastic word formation. In: Nicole Dehé, Ray Jackendoff, Andrew McIntyre and Silke Urban (eds.), Verb-Particle Explorations, 21-41. Berlin/New York: Mouton de Gruyter.

Collins, Chris and Höskuldur Thráinsson

1996 VP-internal structure and object shift in Icelandic. Linguistic Inquiry 27(3): 391-344.

Dehé, Nicole

2002 Particle Verbs in English. Syntax, Information Structure, and Intonation. Amsterdam/ Philadelphia: Benjamins.

Dehé, Nicole

2005 The optimal placement of $u p$ and $a b$ - A comparison. Journal of Comparative Germanic Linguistics 8(3): 185-224.

Dehé, Nicole, Ray Jackendoff, Andrew McIntyre and Silke Urban

2002 Introduction. In: Nicole Dehé, Ray Jackendoff, Andrew McIntyre and Silke Urban (eds.), Verb-Particle Explorations, 1-20. Berlin/New York: Mouton de Gruyter.

Dikken, Marcel den

1995 Particles. On the Syntax of Verb-Particle, Triadic, and Causative Constructions. Oxford: Oxford University Press.

Diesing, Molly

1997 Yiddish VP order and the typology of object movement in Germanic. Natural Language and Linguistic Theory 15(2): 369-427.

Donaldson, Bruce C.

1993 A Grammar of Afrikaans. Berlin/New York: Mouton de Gruyter.

Elenbaas, Marion

2007 The Synchronic and Diachronic Syntax of the English Verb-Particle Combination. Utrecht: LOT.

Emonds, Joseph

1985 A Unified Theory of Syntactic Categories. Dordrecht: Foris.

Farrell, Patrick

2005 English verb-preposition constructions: Constituency and order. Language 81(1): 96137.

Gries, Stefan Thomas

2003 Multifactorial Analysis in Corpus Linguistics. A Study of Particle Placement. New York/ London: Continuum International Publishing Group.

Grimshaw, Jane

1997 Projection, heads, and optimality. Linguistic Inquiry 28(3): 373-422.

Haiden, Martin

2006 Verb particle constructions. In: Martin Everaert and Henk van Riemsdijk (eds.), The Blackwell Companion to Syntax. Vol. 5, 344-375. Oxford: Blackwell.

Haider, Hubert

1997 Precedence among predicates. Journal of Comparative Germanic Linguistics 1: 3-41. 
Harbert, Wayne

2007 The Germanic Languages. Cambridge: Cambridge University Press.

Hoekstra, Teun

1988 Small clause results. Lingua 74: 101-139.

Holmberg, Anders and Jan Rijkhoff

1998 Word order in the Germanic languages. In: Anna Siewierska (ed.), Constituent Order in the Languages of Europe, 75-104. Berlin/New York: Mouton de Gruyter.

Jackendoff, Ray

2002 English particle constructions, the lexicon, and the autonomy of syntax. In: Nicole Dehé, Ray Jackendoff, Andrew McIntyre and Silke Urban (eds.), Verb-Particle Explorations, 67-94. Berlin/New York: Mouton de Gruyter.

Jacobs, Neil G.

2005 Yiddish. A Linguistic Introduction. Cambridge: Cambridge University Press.

Jacobs, Neil G., Ellen F. Prince and Johan van der Auwera

1994 Yiddish. In: Ekkehard König and Johan van der Auwera (eds.), The Germanic Languages, 388-419. London/New York: Routledge.

Johnson, Kyle

1991 Object positions. Natural Language and Linguistic Theory 9: 577-636.

Kayne, Richard S.

1985 Principles of particle constructions. In: Jacqueline Guéron, Hans Georg Oberauer and Jean-Yves Pollock (eds.), Grammatical Representations, 101-140. Dordrecht: Foris.

Kayne, Richard S.

1998. Overt vs. covert movement. Syntax 1: 128-191.

Koizumi, Masatoshi

1993 Object agreement phrases and the split VP hypothesis. In: Colin Phillips and Jonathan

D. Bobaljik (eds.), Papers on Case and Agreement I: MIT Working Papers in Linguistics 18, 99-148, Cambridge, MA: MIT Working Papers in Linguistics.

Lüdeling, Anke

2001 Particle Verbs and Similar Constructions in German. Stanford: CSLI.

Marle, Jaap van

2002 Dutch separable compound verbs: Words rather than phrases? In: Nicole Dehé, Ray Jackendoff, Andrew McIntyre and Silke Urban (eds.), Verb-Particle Explorations, 211232. Berlin/New York: Mouton de Gruyter.

McIntyre, Andrew

2007 Particle verbs and argument structure. Language and Linguistics Compass 1(4): $350-$ 367.

Müller, Stefan

2002 Complex Predicates. Verbal Complexes, Resultative Constructions, and Particle Verbs in German. Stanford: CSLI.

Neeleman, Ad

2002 Particle placement. In: Nicole Dehé, Ray Jackendoff, Andrew McIntyre and Silke Urban (eds.), Verb-Particle Explorations, 141-164. Berlin/New York: Mouton de Gruyter.

Neeleman, Ad and Fred Weerman

1993 The balance between syntax and morphology: Dutch particles and resultatives. Natural Language and Linguistic Theory 11: 433-475.

Olsen, Susan

1996 Partikelverben im deutsch-englischen Vergleich. In: Ewald Lang and Gisela Zifonun Olsen, Susan (eds.), Deutsch - typologisch, 165-190. Berlin/New York: Mouton de Gruyter.

1997 Über den lexikalischen Status englischer Partikelverben. In: Elisabeth Löbel and Gisa Rauh (eds.), Lexikalische Kategorien und Merkmale, 45-71. Tübingen: Niemeyer. 
Olsen, Susan

2000 Against incorporation. In: Johannes Dölling and Thomas Pechmann (eds.), Linguistische Arbeitsberichte 74, 149-172. University of Leipzig: Department of Linguistics.

Ramchand, Gillian and Peter Svenonius

2002 The lexical syntax and lexical semantics of the verb-particle construction. In: Line Mikkelsen and Christopher Potts (eds.), WCCFL 21 Proceedings, 387-400. Somerville, MA: Cascadilla Press.

Santorini, Beatrice

1992 Variation and change in Yiddish subordinate clause word order. Natural Language and Linguistic Theory 10(4): 595-640.

Stiebels, Barbara and Dieter Wunderlich

1994 Morphology feeds syntax: The case of particle verbs. Linguistics 32: 913-968.

Svenonius, Peter

1994 Dependent nexus: Subordinate predication structures in English and the Scandinavian languages. Ph.D. dissertation, University of California, Santa Cruz.

Svenonius, Peter

1996a The optionality of particle shift. Working Papers in Scandinavian Syntax 57: 47-75.

Svenonius, Peter

1996b The verb-particle-alternation in the Scandinavian languages. Ms. University of Tromsø.

Thráinsson, Höskuldur

2007 The Syntax of Icelandic. Cambridge: Cambridge University Press.

Thráinsson, Höskuldur, Hjalmar P. Peterson, Jógvan í Lon Jacobsen and Zakaris Svabo Hansen

2004 Faroese. An Overview and Reference Grammar. Tórshavn: Føroya Fróðskaparfelag.

Toivonen, Ida

2002 Swedish particles and syntactic projection. In: Nicole Dehé, Ray Jackendoff, Andrew McIntyre and Silke Urban (eds.), Verb-Particle Explorations, 191-209. Berlin/New York: Mouton de Gruyter.

Toivonen, Ida

2003 Non-Projecting Words. A Case Study of Swedish Particles. Dordrecht: Kluwer.

Vikner, Sten

2001 Verb movement variation in Germanic and optimality theory. Habilitationsschrift, University of Tübingen.

Wurmbrand, Susi

1998 Heads or phrases? Particles in particular. In: Wolfgang Kehrein and Richard Wiese (eds.), Phonology and Morphology of the Germanic Languages, 267-295. Tübingen: Niemeyer.

Wurmbrand, Susi

2000 The structure(s) of particle verbs. Manuscript, McGill University.

Zeller, Jochen

2001 Particle Verbs and Local Domains. Amsterdam/Philadelphia: Benjamins.

Zeller, Jochen

2002 Particle verbs are heads and phrases. In: Nicole Dehé, Ray Jackendoff, Andrew McIntyre and Silke Urban (eds.), Verb-Particle Explorations, 233-267. Berlin/New York: Mouton de Gruyter. 